\title{
POTENSI BIVALVIA SEBAGAI BIOINDIKATOR PENCEMARAN LOGAM DI WILAYAH PESISIR
}

\author{
Oleh \\ Triyoni Purbonegoro' ${ }^{1}$ )
}

\begin{abstract}
POTENTIAL OF BIVALVE AS BIOINDICATOR OF METAL POLLUTION IN

THE COASTAL AREA. Bioaccumulation database using various species of marine bivalves is useful to determine which species are suitable as bioindicators in pollution monitoring. In general, metal bioaccumulation in bivalve varies in every location and influenced by the biokinetics of each species depending on the environmental condition. Increasing accumulation of one metal will enhance the accumulation of other metal in bivalve tissue. This needs to be taken into account in interpreting metal concentrations in bivalve. Oysters and mussels have the potential as bio-indicators of metals, especially $\mathrm{Cu}$ and $\mathrm{Zn}$, while scallops are more potential as bioindicators of $\mathrm{Cd}$ and $\mathrm{Zn}$. Meanwhile, clams has the potential as a bioindicators of Zn. Change in shape (malformation) of bivalve shells due to heavy metal accumulation also observed. The rough structure, attachment of minerals to the shell, and thickening of the shell layer are some forms of changes in bivalve shell morphology.
\end{abstract}

\section{PENDAHULUAN}

Bivalvia merupakan biota yang populer digunakan untuk mendeteksi pencemaran lingkungan, disebabkan karena hidupnya yang berasosiasi dengan sedimen, kebiasaan makannya sebagai filter-feeder, dan kemampuannya mengakumulasi bahan pencemar (Zuykov et al., 2013; Gerhardt, 2002; D'costa et al., 2018). Kemampuan bioakumulasinya yang tinggi menyebabkan konsentrasi bahan kimia yang sebelumnya tidak terdeteksi dalam air dapat ditemukan dalam tubuh bivalvia (Zuykov et al. 2013). Sebagai biota akumulator atau biasa disebut 'sentinel', bivalvia harus tahan terhadap tekanan lingkungan dan bersifat menetap (sedentary) sehingga dapat menggambarkan suatu wilayah

\footnotetext{
1) Pusat Penelitian Oseanografi, LIPI
}

kajian. Organisme 'sentinel' juga harus memiliki kelimpahan yang tinggi agar dapat menyediakan sampel untuk dianalisis, serta memiliki sebaran yang luas untuk dapat dibandingkan antarlokasi (Gerhardt, 2002).

Selama beberapa dekade, berbagai spesies bivalvia telah diteliti untuk menentukanpotensinyasebagaiorganisme bioindikator atau biomonitoring. Pada tahun 1975, program "The Mussel Watch" di Amerika Serikat memulai menggunakan tiram dan kerang dalam upaya monitoring empat macam polutan di lingkungan laut, yaitu radionuklida buatan, petroleum hidrokarbon, hidrokarbon terklorinasi, dan logam (Goldberg \& Bertine, 2000). Dalam program tersebut kerang biru (Mytilus 
edulis) digunakan sebagai bioindikator disebabkan sebarannya yang luas, mudah dipindahkan dari satu lokasi ke lokasi lain (monitoring aktif), kelimpahan yang tinggi, laju akumulasi bahan pencemar yang tinggi, serta siklus hidup yang lama (tiga tahun) memungkinkan monitoring jangka panjang (Gerhardt, 2002). Beberapa jenis bivalvia yang umum digunakan dalam kajian pencemaran di lingkungan kawasan pesisir Indonesia, antara lain adalah kerang hijau, Perna viridis (Wendling et al., 2013; Suprapti et al., 2016; Rist et al., 2016; Dwiyitno et al., 2016; Riani et al. 2018), kerang simping (Amusium pleuronectes) (Azhar et al., 2012), dan kerang darah, Anadara granosa (Suprapti, 2008) (Gambar 1).

\section{Biomonitoring}

pencemaran

membutuhkan data respon biologi, seperti

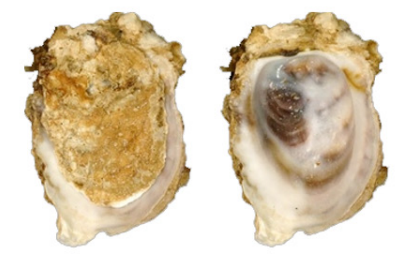

A

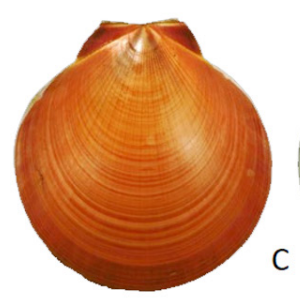

data bioakumulasi, biomarker, observasi morfologi dan perilaku, serta analisis pada tingkat komunitas (Zuykov, 2013). Setiap organisme memiliki sensitivitas yang berbeda terhadap bermacam polutan, dan tidak ada satu jenis organisme yang mampu atau cocok untuk mendeteksi semua jenis bahan pencemar (Waykar \& Deshmukh, 2012). Untuk itu, database bioakumulasi dengan menggunakan bermacam jenis bivalvia berguna untuk menentukan spesies mana yang cocok digunakan sebagai bioindikator dalam kegiatan monitoring pencemaran. Tulisan ini menjelaskan secara singkat penggunaan bivalvia dalam monitoring pencemaran logam berat di wilayah pesisir melalui pendekatan analisis bioakumulasi logam dalam jaringan lunak bivalvia dan pengaruhnya pada morfologi cangkang.
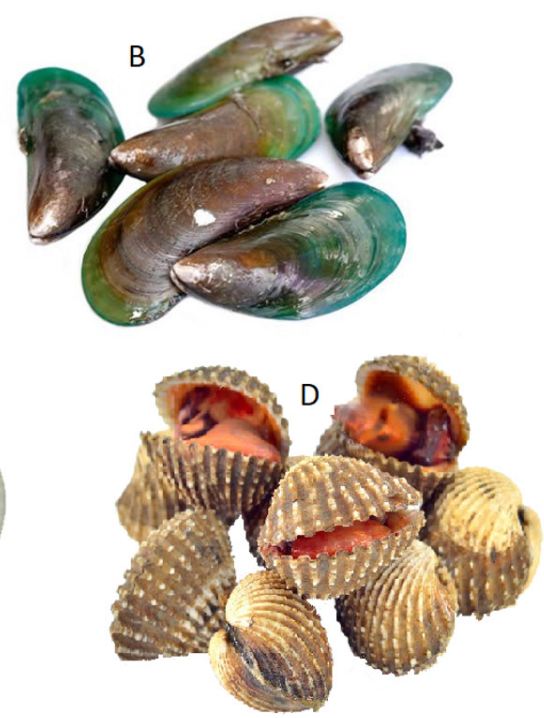

Gambar 1. Beberapa contoh jenis bivalvia yang umum digunakan sebagai bioindikator pencemaran di lingkungan pesisir yaitu, (A) golongan tiram (oyster), Saccostrea cucullata, (B) golongan remis (mussels), Perna viridis, (C) golongan simping (scallops), Amusium pleuronectes, dan (D) golongan kepah (clams), Anadara granosa. 


\section{KONSENTRASI LOGAM DALAM JARINGAN LUNAK BIVALVIA}

Wang \& Lu (2017) merangkum konsentrasi beberapa logam $(\mathrm{Cd}, \mathrm{Cr}, \mathrm{Cu}$, $\mathrm{Ni}, \mathrm{Pb}, \mathrm{Zn}$, dan $\mathrm{Hg}$ ) dalam beberapa jenis bivalvia yang diambil dari wilayah yang berbeda di kawasan Asia (Tabel 1). Secara umum konsentrasi logam dalam tubuh bivalvia berbeda-beda pada setiap lokasi dan dipengaruhi oleh biokinetik masingmasing spesies yang tergantung kondisi lingkungan tempat biota tersebut hidup. Hal tersebut pada akhirnya berpengaruh terhadap proses bioakumulasi logam dalam tubuh bivalvia.

\section{Konsentrasi logam dalam bivalvia golongan tiram (oysters)}

Secara umum, konsentrasi $\mathrm{Cu}$ dan $\mathrm{Zn}$ dalam tubuh tiram lebih tinggi dibandingkan logam lain (Tabel 1). Konsentrasi $\mathrm{Cu}$ dan $\mathrm{Zn}$ dalam tiram dari wilayah yang relatif tidak tercemar masing-masing berkisar antara 50-100 dan 500-2000 $\mu \mathrm{g} / \mathrm{g}$. Sementara itu, akumulasi $\mathrm{Cu}$ dan $\mathrm{Zn}$ tertinggi tercatat ditemukan pada tiram $C$. hongkongensis yang berasal dari muara-muara di bagian selatan China dengan konsentrasi masing-masing 12.000 dan 17000 $\mu \mathrm{g} / \mathrm{g}$. Konsentrasi yang sangat tinggi menyebabkan warna biru pada jaringan lunak bivalvia tersebut (Gambar 2). Konsentrasi tinggi tersebut disebabkan limbah dari industri-industri di sekitar wilayah tersebut (Wang et al., 2014).

Pertanyaan yang kemudian muncul adalah mengapa tiram mampu mentolerir konsentrasi yang sangat tinggi dan tetap hidup. Beberapa peneliti menduga bahwa tiram memiliki mekanisme detoksifikasi yang spesifik. Pada tiram yang hidup di perairan tercemar, $\mathrm{Cu}$ dan $\mathrm{Zn}$ dalam konsentrasi tinggi berikatan dengan oksigen atau nitrogen, sedangkan pada tiram yang hidup di lingkungan yang relatif bersih, kedua logam tersebut berikatan dengan sulfur. Hal tersebut memungkinkan tiram dapat secara efisien melakukan detoksifiksi, dengan cara menyimpan kelebihan $\mathrm{Cu}$ dan $\mathrm{Zn}$ dalam bentuk logam-logam yang berikatan dengan oksigen dan nitrogen dalam tubuh tanpa berakibat fatal bagi kehidupannya (Wang \& Lu, 2017).
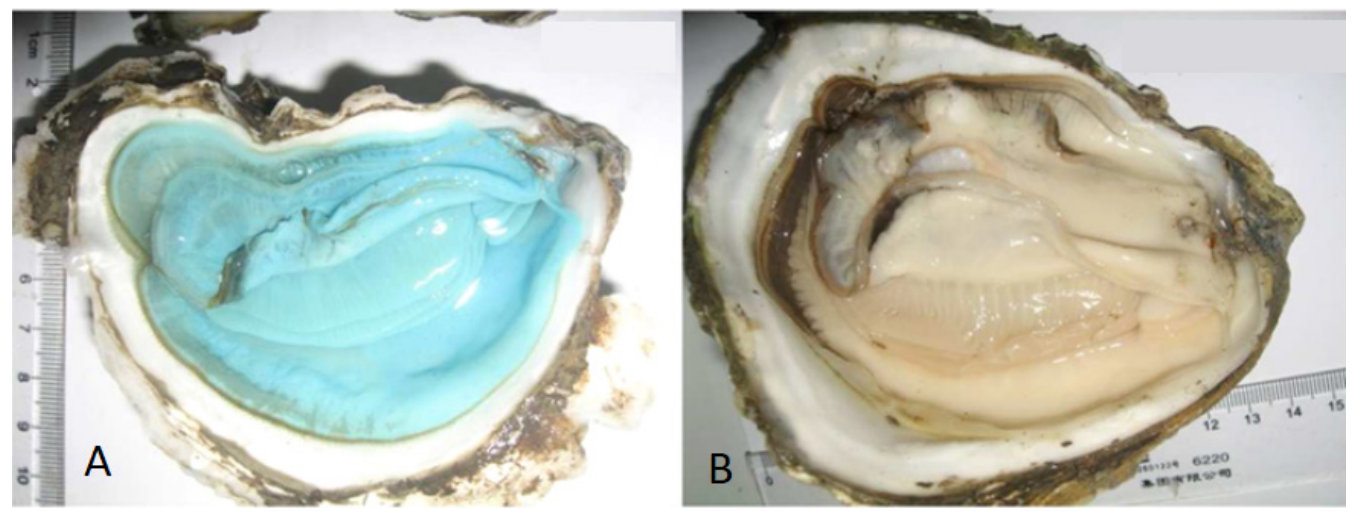

Gambar 2. Perbedaan penampakan jaringan lunak antara tiram C. hongkongensis yang berwarna biru, karena memiliki kandungan $\mathrm{Cu}$ yang sangat tinggi (A), dan tiram sejenis yang hidup di lingkungan tidak tercemar (Tan et al., 2015). 
Konsentrasi $\mathrm{Zn}$ yang tinggi, akan memicu akumulasi $\mathrm{Cd}$ dalam tubuh tiram. Salah satu konsentrasi Cd tertinggi dalam tubuh tiram ditemukan di China $(>10$ $\mu \mathrm{g} / \mathrm{g}$ ). Hasil pengukuran konsentrasi $\mathrm{Cd}$ dalam air dan sedimen di lokasi tersebut, tidak sepenuhnya berkorelasi dengan konsentrasi $\mathrm{Cd}$ dalam tiram. Penelitian yang dilakukan oleh Liu \& Wang (2013) menunjukkan akumulasi $\mathrm{Zn}$ memfasilitasi penyerapan $\mathrm{Cd}$ dalam tiram. Hal ini diduga, karena $\mathrm{Zn}$ memicu metalotionein dalam tiram untuk mengikat $\mathrm{Cd}$ lebih kuat. Oleh karena itu, pencemaran yang menyebabkan peningkatan konsentrasi $\mathrm{Zn}$ diduga akan berdampak juga pada peningkatan $\mathrm{Cd}$ dalam tiram. Pemaparan $\mathrm{Zn}$ dan $\mathrm{Cu}$ juga berdampak pada peningkatan $\mathrm{Hg}$ dalam tubuh tiram. Tiram merupakan organisme yang mampu meregulasi Ni dalam tubuhnya. Tiram akan terus mengakumulasi $\mathrm{Ni}$ hingga mencapai kondisi konstan (plateu). Mekanisme regulasi logam tersbut hingga kini masih terus dipelajari. Sementara itu, konsentrasi $\mathrm{Pb}$ dalam tiram relatif rendah $(<4 \mu \mathrm{g} / \mathrm{g})$, meskipun di beberapa lokasi yang tercemar, $\mathrm{Pb}$ ditemukan dalam konsentrasi tinggi. Tiram dianggap bukan merupakan organisme pengakumulasi $\mathrm{Cr}$ yang baik karena $\mathrm{Cr}$ dalam air memiliki spesiasi yang kompleks dan diduga tidak bersifat bioavailable bagi tiram (Wang \& $\mathrm{Lu}, 2017)$.

\section{Konsentrasi logam dalam bivalvia golongan remis (mussels)}

Konsentrasi Cd dalam remis di semua lokasi pada umumnya relatif rendah $(<2 \mu \mathrm{g} / \mathrm{g})$ (Tabel 1). Konsentrasi $\mathrm{Cd}$ yang rendah, juga ditemukan dalam tubuh Perna viridis di Teluk Jakarta, yakni berkisar antara 0,097-0,133 $\mu \mathrm{g} / \mathrm{g}$ (Riani et al., 2018). Remis sering digunakan dalam pemantauan pencemaran $\mathrm{Cd}$, meskipun apabila dibandingkan dengan tiram, bivalvia golongan remis (mussels) memiliki potensi bioakumulasi $\mathrm{Cd}$ yang rendah, yang disebabkan kemampuan mengeluarkan logam tersebut dari dalam tubuh secara lebih efektif. Hal ini menyebabkan konsentrasi $\mathrm{Cd}$ dalam remis lebih rendah daripada dalam tiram (Wang \& Lu, 2017).

Seperti halnya pada tiram, konsentrasi $\mathrm{Cu}$ dan $\mathrm{Zn}$ pada remis lebih tinggi dari logam lainnya. Meski demikian, konsentrasi $\mathrm{Cu}$ dan $\mathrm{Zn}$ dalam remis tersebut relatif rendah (masing-masing $<20$ dan $<200 \mu \mathrm{g} / \mathrm{g}$ ). Remis mampu meregulasi $\mathrm{Cu}$ dan $\mathrm{Zn}$ dalam tubuhnya, seperti halnya tiram meregulasi Ni dalam tubuhnya. Meski demikian, tidak banyak informasi yang menunjukkan kemampuan remis dalam meregulasi Ni (Wang \& Lu, 2017). Pada beberapa penelitian konsentrasi Ni dalam remis berkisar antara $<5$ sampai $33 \mu \mathrm{g} / \mathrm{g}$ 
sedangkan konsentrasi $\mathrm{Pb}$ dalam remis pada umumnya sebesar $<5$ sampai 59$64 \mu \mathrm{g} / \mathrm{g}$. Konsentrasi $\mathrm{Cr}$ dalam tubuh remis umumnya $<6 \mu \mathrm{g} / \mathrm{g}$ yang diprediksi sebesar 13-38\% berasal dari Cr (VI) terlarut (Wang \& Lu, 2017).

\section{Konsentrasi logam dalam bivalvia golongan simping (scallops)}

Konsentrasi $\mathrm{Cd}$ dalam tubuh simping khususnya dalam ginjal tergolong tinggi. Konsentrasi minimum $\mathrm{Cd}$ dalam simping tercatat $0.3 \mu \mathrm{g} / \mathrm{g}$ dan maksimum sebesar 160-332 $\mu \mathrm{g} / \mathrm{g}$ (Tabel 1). Oleh karena itu, simping tergolong hewan hiperakumulator $\mathrm{Cd}$. Konsentrasi tinggi $\mathrm{Cd}$ dalam tubuh simping disebabkan oleh kemampuan efisiensi asimilasi yang tinggi dan laju pengeluaran yang rendah. Sebaliknya, konsentrasi $\mathrm{Cu}$ dalam simping relatif rendah berkisar antara 2-166 $\mu \mathrm{g} / \mathrm{g}$. Sementara itu, simping juga dapat digolongkan sebagai hewan hiperakumulator $\mathrm{Zn}$ disebabkan kemampuannya mengakumulasi $\mathrm{Zn}$ dalam konsentrasi tinggi. Penelitian logam lain seperti $\mathrm{Ni}, \mathrm{Pb}, \mathrm{Cr}$ dan $\mathrm{Hg}$ tidak terlalu banyak ditemukan atau dalam konsentrasi yang tidak terdeteksi. Penelitian Azhar et al. (2012) di kawasan pesisir Demak, Jawa Tengah menemukan konsentrasi $\mathrm{Cd}, \mathrm{Cu}$ dan $\mathrm{Cr}$ dalam simping Amusium pleuronectes masing-masing sebesar 5.9-8 $\mu \mathrm{g} / \mathrm{g}, 8.9-9.5 \mu \mathrm{g} / \mathrm{g}$, dan 0.7 $\mu \mathrm{g} / \mathrm{g}$.

\section{Konsentrasi logam dalam bivalvia golongan kepah (clams)}

Konsentrasi Cd umumnya $<2$ $\mu \mathrm{g} / \mathrm{g}$ namun ditemukan tinggi di beberapa tempat. Kisaran $\mathrm{Cu}$ dalam kepah relatif sempit dan tidak cukup informasi yang menjelaskan apakah kepah dapat meregulasi $\mathrm{Cu}$ dalam tubuhnya atau tidak. Pan dan Wang (2009) menjelaskan bahwa Cu dalam kepah Ruditapes philippinarium dikeluarkan dengan cepat dari dalam tubuh. Sementara itu variasi konsentrasi Zn dalam kepah tergolong dalam kisaran sempit, kemungkinan disebabkan oleh kemampuan regulasi logam tersebut oleh kepah. Konsentrasi $\mathrm{Ni}$ dan $\mathrm{Pb}$ di beberapa daerah masing-masing sebesar $1-5 \mu \mathrm{g} / \mathrm{g}$ dan $<2 \mu \mathrm{g} / \mathrm{g}$. Meski demikian, konsentrasi $\mathrm{Pb}$ di beberapa tempat dapat mencapai konsentrasi yang cukup tinggi, misalnya di Muara Likas, Malaysia yakni sebesar 4,74 $\pm 2,37 \mu \mathrm{g} / \mathrm{g}$ (Wang et al., 2017). 
Tabel 1. Konsentrasi logam berat dalam bivalvia di wilayah Asia ( $\mu \mathrm{g} / \mathrm{g}$ berat kering).

\begin{tabular}{|c|c|c|c|c|c|c|c|c|}
\hline Lokasi & Spesies & Cd & $\mathbf{C u}$ & Zn & $\mathbf{N i}$ & $\mathbf{P b}$ & $\mathrm{Cr}$ & $\mathrm{Hg}$ \\
\hline & Tiram (Oysters) & & & & & & & \\
\hline $\begin{array}{l}\text { Teluk Persia } \\
\text { dan Teluk } \\
\text { Oman, Iran }\end{array}$ & $\begin{array}{l}\text { Saccostrea } \\
\text { cucullata }\end{array}$ & $10 \pm 5,6$ & - & - & - & $0,72 \pm 0,35$ & - & - \\
\hline $\begin{array}{l}\text { Haipong- } \\
\text { Halong, } \\
\text { Vietnam }\end{array}$ & $\begin{array}{l}\text { Saccostrea } \\
\text { glomerata }\end{array}$ & $3,53-12,7$ & $238-1598$ & $824-3202$ & - & $0,79-6,20$ & $0,81-4,47$ & - \\
\hline $\begin{array}{l}\text { Muara } \\
\text { Jiulongjiang, } \\
\text { Cina }\end{array}$ & C. hongkongensis & 11 & 12000 & 17000 & 7,4 & 1,3 & 11 & - \\
\hline \multirow[t]{2}{*}{$\begin{array}{l}\text { Muara } \\
\text { Bakam, } \\
\text { Malaysia }\end{array}$} & $\begin{array}{l}\text { Saccostrea } \\
\text { cucullata }\end{array}$ & - & $63 \pm 0,14$ & $109 \pm 0,2$ & - & - & - & - \\
\hline & Remis (mussels) & & & & & & & \\
\hline $\begin{array}{l}\text { Selat Malaka, } \\
\text { Malaysia }\end{array}$ & Perna viridis & $1,47 \pm 0,69$ & $12,9 \pm 16$ & $92,1 \pm 24,3$ & $18,9 \pm 31,4$ & $10,7 \pm 10,4$ & - & - \\
\hline $\begin{array}{l}\text { Laut } \\
\text { mediterania, } \\
\text { Libya }\end{array}$ & $\begin{array}{l}\text { Modiulus } \\
\text { galloprovincialis }\end{array}$ & $0,63-2,41$ & $3,56-5,69$ & $141-197$ & $1-5,03$ & $0,44-0,71$ & $0,37-0,71$ & $0,045-0,069$ \\
\hline $\begin{array}{l}\text { Pantai } \\
\text { Qingdao, } \\
\text { Cina }\end{array}$ & Mytilus edulis & 1,5 & 9 & 70 & 3 & 1,8 & - & - \\
\hline \multirow[t]{2}{*}{$\begin{array}{l}\text { Changseon, } \\
\text { Korea }\end{array}$} & $\begin{array}{l}\text { Modiulus } \\
\text { galloprovincialis }\end{array}$ & $0,197 \pm 0,071$ & $1,5 \pm 0,72$ & $15,9 \pm 4,83$ & $0,36 \pm 0,2$ & $0,16 \pm 0,12$ & $0,23 \pm 0,12$ & $0,007 \pm 0,003$ \\
\hline & $\begin{array}{l}\text { Simping } \\
\text { (Scallops) }\end{array}$ & & & & & & & \\
\hline $\begin{array}{l}\text { Aomori, } \\
\text { Jepang }\end{array}$ & $\begin{array}{l}\text { Patinopecten } \\
\text { yessoensis }\end{array}$ & $160 \pm 34,7$ & $71,1 \pm 5,35$ & $115 \pm 14,9$ & - & - & - & - \\
\hline \multirow[t]{2}{*}{$\begin{array}{l}\text { Teluk } \\
\text { Jiaozhou, } \\
\text { Cina }\end{array}$} & Chlamys farreri & $0,330 \pm 0,027$ & $1,66 \pm 0,48$ & $12,4 \pm 1,60$ & - & - & - & - \\
\hline & Kepah (Clams) & & & & & & & \\
\hline $\begin{array}{l}\text { Muara Likas, } \\
\text { Malaysia }\end{array}$ & Meretrix meretrix & $3,27 \pm 1,46$ & $6,62 \pm 1,30$ & $107 \pm 28,8$ & - & $1,72 \pm 0,58$ & $2,28 \pm 2,60$ & - \\
\hline $\begin{array}{l}\text { Teluk } \\
\text { Gamak, } \\
\text { Korea }\end{array}$ & $\begin{array}{l}\text { Ruditapes } \\
\text { philippinarum }\end{array}$ & $0,5 \pm 0,2$ & $13,6 \pm 0$ & $76,8 \pm 0,3$ & $2,9 \pm 0,3$ & $0,8 \pm 0,2$ & $3,6 \pm 0,5$ & - \\
\hline $\begin{array}{l}\text { Muara Likas, } \\
\text { Malaysia }\end{array}$ & Anadara granosa & $0,63 \pm 0,44$ & $6,89 \pm 1,66$ & $96 \pm 17$ & - & $4,74 \pm 2,37$ & t.t & - \\
\hline
\end{tabular}

(Sumber: Wang \& Lu, 2017)

\section{LOGAM PADA CANGKANG BIVALVIA}

Pada Gambar 3, Zuykov et al. (2013) menunjukkan adanya pengaruh kontaminan terhadap abnormalitas permukaan cangkang internal bivalvia.
Perak (Ag) dalam fase terlarut (Gambar 3a) dan perak nanopartikel (AgNP) (Gambar 3b), menyebabkan morfologi permukaan cangkang internal Mytilus edulis yang semakin kasar. Selain akibat pengaruh logam, abnormalitas struktur cangkang juga ditandai dengan 
munculnya kristal mineral barit $\left(\mathrm{BaSO}_{4}\right)$ yang tampak pada permukaan cangkang internal kerang air tawar Corbicula fluminea (Gambar 3c dan Gambar 3d). Peningkatan konsentrasi mineral barit disebabkan dari limbah yang dikeluarkan oleh beberapa pabrik gelas di sekitar Sungai Maurice, New Jersey, Amerika Serikat. Kemunculan kristal mineral pada cangkang bivalvia juga ditunjukkan dengan adanya kalsit dan aragonite $\left(\mathrm{CaCO}_{3}\right)$, pada permukaan cangkang internal Chlamys varia (Gambar 3e) dan Ostrea edulis (Gambar 3f). Penempelan kristal vaterit (salah satu polimorf dari $\mathrm{CaCO}_{3}$ ) juga tampak pada Corbicula fluminea (Gambar 3g dan Gambar 3h). Hal tersebut menimbulkan deformasi berupa tonjolan pada permukaan cangkang akibat penumpukan mineral vaterit. Deformasi cangkang juga dapat disebabkan oleh pencemaran senyawa tributiltin (TBT) atau merkuri (Hg).
Perubahan bentuk (malformasi) cangkang bivalvia akibat akumulasi logam berat juga ditunjukkan oleh Riani et al. (2018). Perubahan bentuk tersebut ditandai dengan penebalan cangkang kerang hijau Perna viridis hingga 1,5 kali, dibandingkan kerang pada kondisi normal (Gambar 4). Perubahan bentuk disebabkan oleh konsentrasi logam yang tinggi, terutama $\mathrm{Hg}, \mathrm{Pb}$, dan $\mathrm{Sn}$ yang bersifat teratogenik (menyebabkan perubahan struktur morfologi). Hasil analisis komponen utama (principal component analysis/PCA) menunjukkan variabel kualitas air dan logam berat (dalam air dan tubuh kerang hijau) berhubungan dengan perubahan bentuk cangkang kerang hijau tersebut. Variabel kualitas air yang berkontribusi terhadap perubahan bentuk cangkang kerang hijau tersebut, antara lain adalah turbiditas, salinitas, $\mathrm{COD}, \mathrm{NO}_{3}$ dan $\mathrm{pH}$. Sedangkan variabel logam berat, antara lain adalah logam dalam air $(\mathrm{Cd}, \mathrm{Pb}$ dan $\mathrm{Cr})$, serta logam dalam jaringan lunak kerang hijau $(\mathrm{Pb}, \mathrm{Hg}$, dan $\mathrm{Cr})$. 

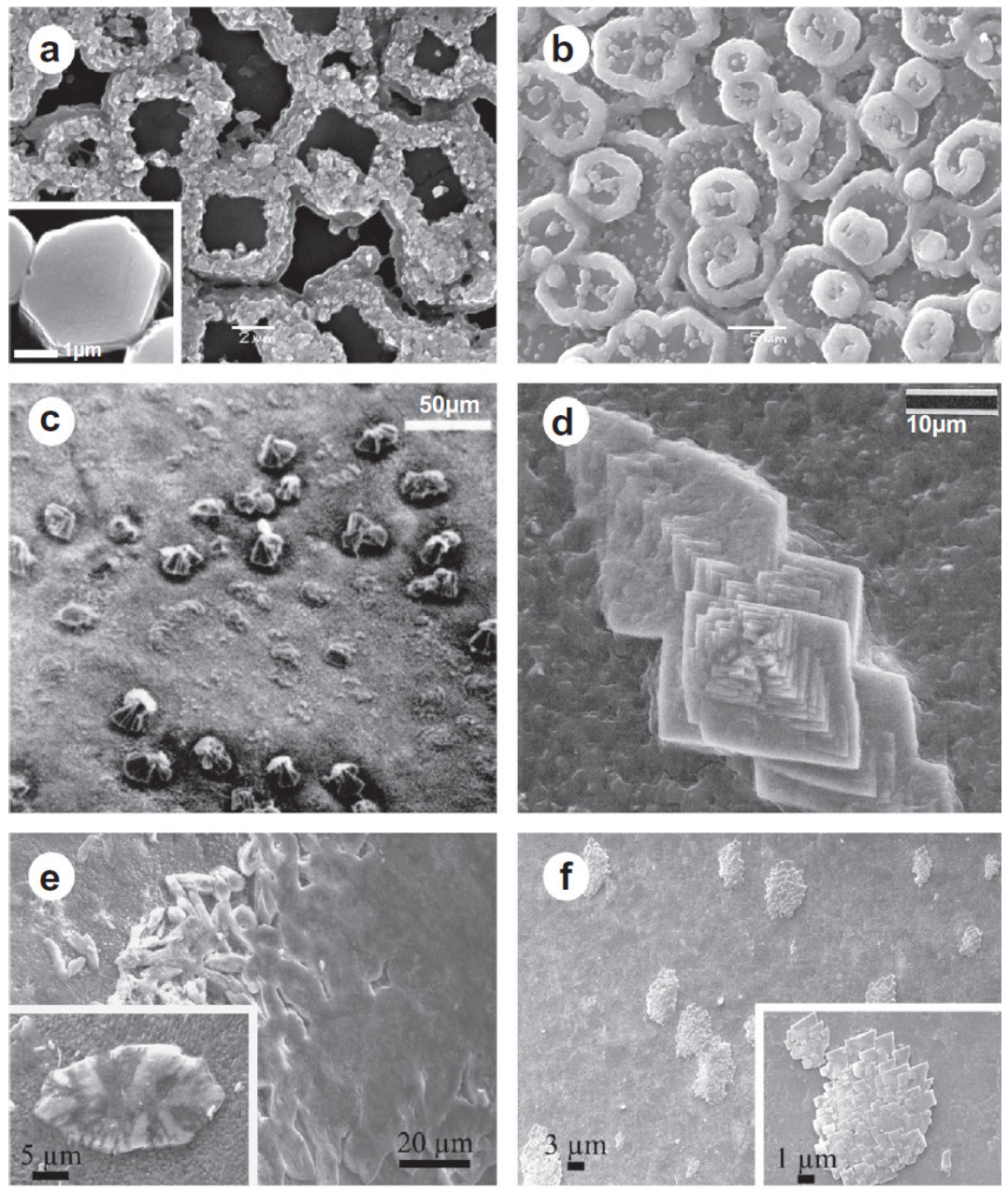

g
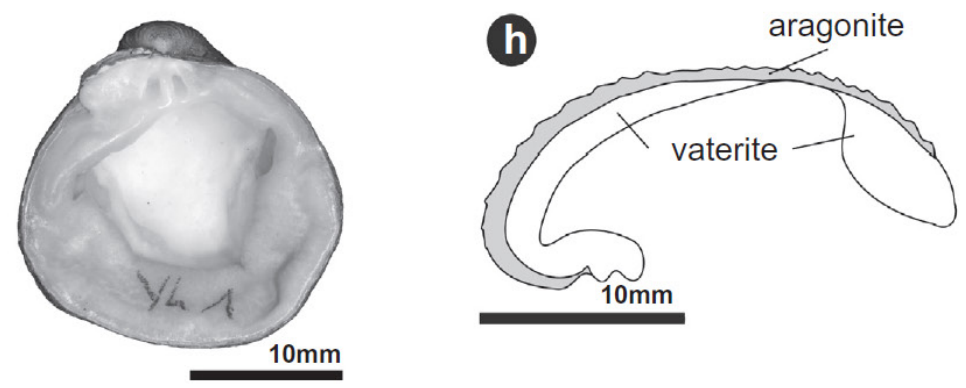

Gambar 3. Gambar hasil pengamatan menggunakan SEM (scanning electron microscope) yang menunjukkan perubahan struktur cangkang beberapa jenis bivalvia akibat kontaminan. Kerang biru Mytilus edulis (a) dan (b), Corbicula fluminea (c) (d) (g) (h), Chlamys varia (e), dan Ostrea edulis (f) (Zuykov et al., 2013). 


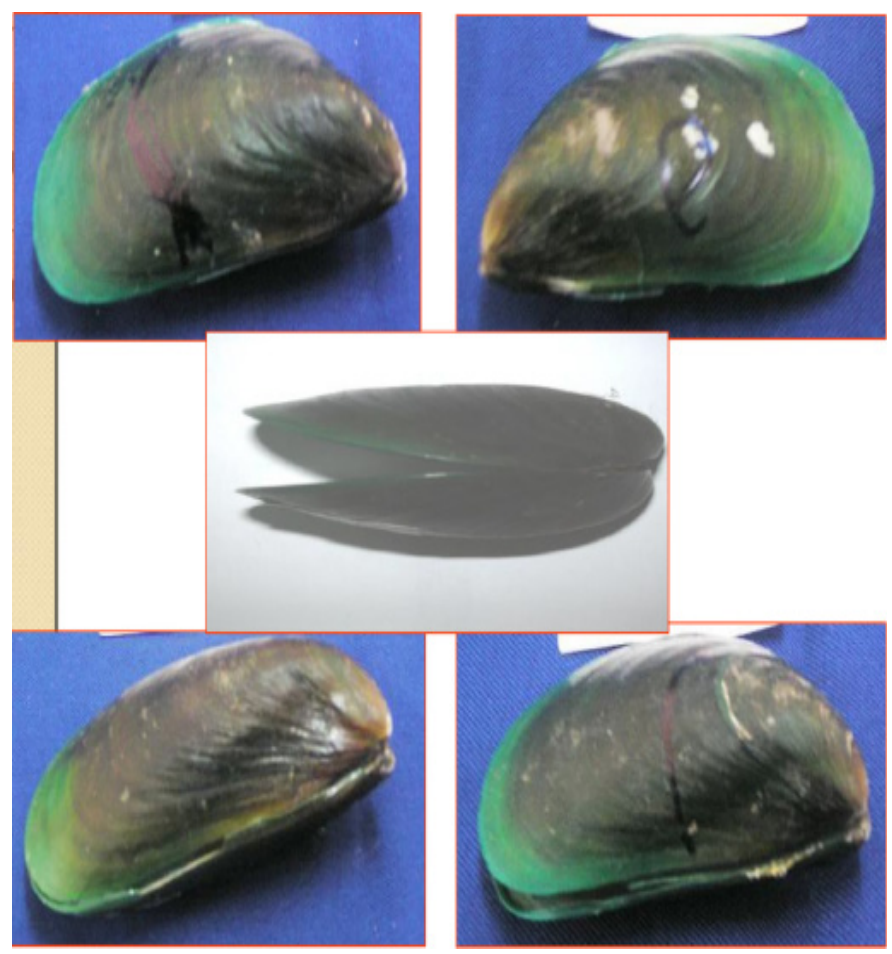

Gambar 4. Perubahan bentuk (malformasi) pada cangkang kerang hijau (Perna viridis) (gambar tengah cangkang normal) akibat pencemaran logam berat (Riani et al., 2018).

\section{PENUTUP}

Database bioakumulasi logam dengan menggunakan bermacam jenis bivalvia berguna untuk menentukan spesies mana yang cocok digunakan sebagai bioindikator. Setiap jenis bivalvia memiliki respon yang berbeda terhadap logam. Peningkatan konsentrasi suatu logam akan berdampak juga pada peningkatan logam lain dalam tubuh bivalvia. Hal ini perlu diperhitungkan dalam menginterpretasikan konsentrasi logam dalam jaringan lunak bivalvia. Sebagai contoh, pencemaran yang menyebabkan peningkatan konsentrasi $\mathrm{Zn}$, diduga akan berdampak juga pada peningkatan $\mathrm{Cd}$ dan $\mathrm{Hg}$ dalam tubuh bivalvia. Bivalvia jenis tiram (oysters) dan remis (mussels) memiliki potensi sebagai bioindikator logam khususnya $\mathrm{Cu}$ dan Zn, sedangkan jenis simping (scallops) lebih berpotensi sebagai bioindikator logam Cd dan Zn. Sementara itu, jenis kepah (clams) berpotensi sebagai bioindikator logam Zn. Perubahan bentuk (malformasi) cangkang kerang karena akumulasi logam berat juga teramati. Struktur kasar, penempelan mineral pada cangkang, dan penebalan lapisan cangkang merupakan beberapa bentuk perubahan morfologi cangkang bivalvia. 


\section{DAFTAR PUSTAKA}

Azhar, H., I. Widowati, dan J. Suprijanto. 2012. Studi kandungan logam berat $\mathrm{Pb}, \mathrm{Cu}, \mathrm{Cd}, \mathrm{Cr}$ pada kerang simping (Amusium pleuronectes), air dan sedimen di perairan Wedung, Demak serta analisis maximum tolerable intake pada manusia. Journal of Marine Research 1(2): 35-44.

D'costa, A.H., Shyama S. K., Praveen. K. M. K., and S. Furtado. 2018. The Backwater Clam (Meretrix casta) as a bioindicator species for monitoring the pollution of an estuarine environment by genotoxic agents. Mutat. Res. Gen Tox. En. 825: 8-14.

Dwiyitno, L. Dsikowitzky, I. Nordhaus, N. Andarwulan, H. E. Irianto, H. N. Lioe, F. Ariyani, S. Kleinertz, and J. Schwarzbauer. 2016. Accumulation patterns of lipophilic organic contaminants in surface sediments and in economic important mussel and fish species from Jakarta Bay, Indonesia. Marine Pollution Bulletin 110 (2): 767-777.

Gerhardt A. 2002. Bioindicator species and their use in bio-monitoring. In: Environmental Monitoring, Vol. 1 (In-yang HI, Daniels JL, eds). Encyclopedia of Life Support Systems (EOLSS), Oxford.

Goldberg, E. D., and K. K. Bertine. 2000.
Beyond the Mussel Watchnew directions for monitoring marine pollution. The Science of the Total Environment 247: 165-174

Liu, F.J., and W. X. Wang, 2013. Facilitated bioaccumulation of cadmium and copper in the oyster Crassostrea hongkongensis solely exposed to zinc. Environ. Sci. Technol. 46: 1670-1677.

M. Zuykov, E. Pelletier, and D.A.T. Harper. Bivalve mollusks in metal pollution studies: from bioaccumulation to biomonitoring: review. Chemosphere 93: 201-208.

Pan, K., and W. X. Wang. 2009. Biodynamics to explain the difference of copper body concentrations in five marine bivalve species. Environ. Sci. Technol. 49: 2137-2143.

Riani, E., M. R. Cordova, and Z. Arifin. 2018. Heavy metal pollution and its relation to the malformation of green mussels cultured in Muara Kamal waters, Jakarta Bay, Indonesia. Marine Pollution Bulletin 133: 664-670.

Rist, SE., K. Assidqi, N. P. Zamani, D. Appel, and M. Lenz. 2016. Suspended micro-sized PVC particles impair the performance and decrease survival in the Asian green 
mussel Perna viridis. Marine Pollution Bulletin 111(1-2): 213-220.

Suprapti, N. H. 2008. Kandungan chromium pada perairan, sedimen dan kerang darah (Anadara granosa) di wilayah pantai sekitar muara sungai Sayung Desa Morosari Kabupaten Demak, Jawa Tengah. BIOMA. 10 (2): 36-40.

Suprapti, N. H., A.N. Bambang, F. Swastawati, and R. A. Kurniasih. 2016. Removal of heavy metals from a contaminated green mussel Perna Viridis (Linneaus, 1758)] Using Acetic Acid as Chelating Agents. Aquatic Procedia 7: 154-159.

Tan, Q.G., Y. Wang, and W. X. Wang. 2015. Speciation of $\mathrm{Cu}$ and $\mathrm{Zn}$ in two colored oyster species determined by X-ray absorption spectroscopy. Environ. Sci. Technol. 49: 6915-6925.

Wang, W.X., K. Pan, Q. G. Tan, L. Guo and S. L. Simpson. 2014. Estuarine pollution of metals in China: science and mitigation. Environ. Sci. Technol. 48: 9975-9976.
Wang, WX. and G. Lu. 2017. Heavy metals in bivalve Mollusks. In : Chemical Contaminants and Residues in Food (Second Edition). 553-594.

Waykar B. and G. Deshmukh. 2012. Evaluation of bivalves as bioindicators of metal pollution in freshwater. Bull. Environ. Contam. Toxicol. 88:48-53.

Wendling, C. C., M. Huhn, N. Ayu, R. Bachtiar, K. Juterzenka and M. Lenz. 2013. Habitat degradation correlates with tolerance to climate-change related stressors in the green mussel Perna viridis from West Java, Indonesia. Marine Pollution Bulletin 71: 222-229.

Zuykov, M., E. Pelletier and D. A. T. Harper. 2013. Bivalve mollusks in metal pollution studies: from bioaccumulation to biomonitoring. Chemosphere 93 (2): 201-208. 